\section{Åben sektion}

\section{Nøgleord}

liberal salafisme; nationalisme; reform; konstitution; demokrati

\section{Reformbevægelsen:}

\section{Liberal salafiyya i Marokko}

\begin{abstract}
Formålet med denne artikel er at diskutere det marokkanske hybridfænomen, liberal salafiyya, sådan som det kom til udtryk i perioden 1930-1960. Fænomenet blev begrebsliggjort af den marokkanske tænker Muhammad 'Ābed al-Jābirī og blev derefter defineret og afgrænset som en ideologisk skole, der opstod i Marokko i 1930'erne og fortsatte efter Marokko opnåede uafhængighed fra Frankrig i 1956. Al-Jābirī argumenterede for, at den liberale salafiyya voksede ud af en sammensmeltning af vestlig liberalisme og traditionel marokkansk salafisme under det franske protektorat (1912-1956). I Marokko kom den liberale salafiyya til at stå langt stærkere end i resten af den arabiske verden. Det blev et nationalt projekt understøttet af reformister som Allāl al-Fāsī and Muhammad al-Wazzānī, men også af Sultan Muhammad V og det konservative religiøse etablissement. De unge reformister fremlagde en "Plan de Réformes", som krævede, at marokkanerne skulle indgå i en moderniseringsproces, men det franske protektorat afviste deres krav. Denne beslutning tilskyndede al-Fāsī og al-Wazzānī til at definere deres eget politiske projekt med henblik på at erstatte det traditionelle politiske system med et konstitutionelt monarki. Men efter en mere end fireårtier lang, sej kamp for indførelsen af et parlamentarisk system og moderne politiske institutioner, indså alFāsī og al-Wazzānī, at Marokko i den postkoloniale periode ikke var klar til at implementere deres politiske tanker.
\end{abstract}

Salafisme er en betegnelse, som hyppigt optræder i offentligheden, medierne og det akademiske miljø. I medierne forbindes salafisme i høj grad med terror, militant aktivisme og ekstremisme, selvom salafisme er langt mere nuanceret end det. Det har medført et langt større fokus på studiet af religiøs og politisk tænkning i moderne islam, og for at anfægte generaliseringer af salafisme har en række forskere omhyggeligt under-

Mounir Ainouz er cand. mag i Mellemøststudier fra Københavns Universitet (2014). Hans forskningsinteresse er primært Nordafrika med særligt fokus på politiske reformer, demokratisering, islamisme og nationalisme. Han har tidligere undersøgt, hvordan den statsejede marokkanske tv-kanal al-Aoula lancerede en serie om den nye familielovgivning, kaldet Moudawana, som blev vedtaget i Marokko i 2004. 
søgt og nuanceret begrebet. Roel Meijers bog Global Salafism: Islam's New Religious Movement og Quiantan Wiktorowiczs artikel "Anatomy of the Salafi Movement" bidrager i denne sammenhæng til en nuancering af begrebet og fortjener opmærksomhed, når emnet salafisme skal behandles. Globalt set inddeles salafismen i fire hovedfraktioner: puritansk salafiyya, politisk salafiyya, salafiyya jihadiyya og hybrid salafiyya, hvor sidstnævnte blev anført af den egyptiske reformist Muhammad Abduh (1849-1905). Men på trods af Meijers og Wiktorowiczs bidrag til en nuancering af begrebet salafisme finder jeg typologiseringen mangelfuld, da den ikke omfatter den marokkanske version af salafisme, nærmere defineret liberal salafiyya.

Denne artikel sigter derfor mod at revidere den fremherskende typologi ved at fokusere på liberal salafiyya i Marokko, som i høj grad er underbelyst i forskningen og anderledes konstrueret end de dominerende salafisme-bevægelser. Et andet vigtigt aspekt er, at der er tale om en bevægelse, der omfavner grundlæggende demokratiske rettigheder, såsom ytringsfrihed og forsamlingsfrihed samt indførelsen af et konstitutionelt monarki, som man kender det i Vesten. Med andre ord ønsker bevægelsen samme civilisationsfremgang og velstand, som Vesten oplevede i begyndelsen af det 20. århundrede. Det gør liberal salafiyya til et interessant studiefelt for en europæisk, såvel som en dansk offentlighed.

Denne artikel tager udgangspunkt Muhammad Ābid alJābirīs definition af marokkansk liberal salafiyya, men bygger videre på hans definition gennem en analyse af de to salafistiske figurer: 'Âllāl al-Fāsī (1910-74) og Muhammad al-Wazzānī (191078). Artiklen undersøger, hvordan al-Fāsīs og al-Wazzānīs visioner underbygger deres salafistiske position i den offentlige debat med henblik på at reformere de politiske institutioner og skabe Marokkos første moderne forfatning. Både al-Fāsī og alWazzānī er fortalere for Abduhs hydbrid salafiyya, men laver en marokkansk præget fortolkning af denne.

\section{Liberal salafiyya til debat}

I 2006 debatterede to fremtrædende tænkere i den arabiske verden, marokkanske Muhammad 'Ābid al-Jābirī (1936-2010) og egyptiske Hassan Hanafī (f. 1935), liberalismens succes i den ara- 
biske verden fra det 18. til det 20. århundrede. I denne debat fremhævede Hanafī, at liberalismen til trods for at den liberale tænkning levede i bedste velgående i Egypten, aldrig var blevet forankret i det egyptiske samfund eller i resten af den arabiske verden (Al-Jābirī2006, 58-9). Al-Jābirī stillede i denne sammenhæng spørgsmålstegn ved, hvorvidt det forfejlede liberalismeprojekt i Egypten afspejlede liberalismens gang i resten af den arabiske verden. Han erkendte, at den økonomiske liberalisme ikke havde haft succes i Marokko, men understregede samtidig, at den intellektuelle liberalisme havde haft en langt større succes. Det skyldtes primært, at såkaldt vestlig modernitet ikke havde kollideret med salafismen i Marokko, sådan som den havde gjort i Egypten. Den marokkanske gren af salafismen omfavnede modernitet og liberale værdier inden for en national, arabisk og islamisk ramme. Samtidig havde bevægelsen stærke nationalistiske undertoner, moderniseringsaspirationer og afspejlede et ønke om selvstændighed, som vandt genklang i den urbane del af Marokko under det franske protektorat (19121956).

Det er denne marokkanske salafiyya-bevægelse, som opstod i Marokko i 1930'erne og fortsatte efter landets uafhængighed i 1956, al-Jābirī døbte liberal salafiyya. Ifølge al-Jābirī opererede liberalismen og salafismen $i k k e$ som to uafhængige størrelser i Marokko, men som en hybrid, der havde en langt større gennemslagskraft i Marokko end i resten af Mellemøsten. Salafismen blev derfor i Marokko et nationalt projekt støttet af det religiøse etablissement, den intellektuelle og politiske elite og Sultan Mohammed V (ibid. 71). I begyndelsen af 1930'erne igangsatte salafiyya-bevægelsens medlemmer en diskussion om, hvorvidt det marokkanske samfund kunne reformeres og omfavne modernitet uden at give afkald på sin islamiske identitet. Bevægelsen erkendte, at det var nødvendigt at forny den mālikitiske islamiske tradition for at opnå samme sociale, økonomiske og politiske udvikling som i Vesten. For at opbygge et samfund på niveau med Vesten var det først og fremmest nødvendigt, at itjihad var i overensstemmelse med den mālikitiske juridiske tænkning. Uden støtte fra gejstlige ville moderniserings- og reformeringsprocessen møde modstand fra befolkningen, som i høj grad var autoritetstro mod 'ulamà'. Det lykkedes, ifølge al-Jābirī, for marokkanske reformister (intellektuelle og gejstlige) at omfavne liberale værdier som pluralisme, individu- 
alisme og demokrati. Pluralisme vil politisk sige, at beslutninger blev taget i parlamentet, hvor politiske partier repræsenterede folket. Individualisme, at individet havde mulighed for at ytre sig, og demokrati, at magten lå hos folket. Denne omfavnelse fortsatte, på trods af at den liberale salafiyya-bevægelse efter selvstændigheden blev splittet i to grupperinger på grund af personlige fejder mellem frontfigurerne i bevægelsen og på grund af den ideologiske retning, landet skal bevæge sig. Den første gruppe blev ledet af den konservative leder al-Fāsī, der mente, at islam burde spille en stor rolle, mens liberalismen skulle spille en mindre rolle i forhold til at finde svar på de sociale, økonomiske og politiske problemstillinger i landet. Den anden gruppe blev ledet af al-Wazzānī, der ligeledes argumenterede for vigtigheden af at udtænke et nyt socialt, økonomisk og politisk system. Men i modsætning til al-Fāsī ønskede han et system, hvor liberalismen spillede en langt mere central rolle end islam (ibid. 71-2).

\section{Den spirende neosalafiyya og nationalisme}

Nationalistbevægelsen, som så dagens lys i begyndelsen af 1930'erne, inkorporerer elementer fra både salafismen og liberalismen. Derved opstod det, som al-Jābirī definerede som liberal salafiyya. Det var også en periode, hvor salafismen udviklede sig til neosalafiyya (Abun-Nasr 1966, 496), som var en salafiyyakonstruktion, der gik fra at beskæftige sig med mindre sociale aspekter til langt alvorligere politiske problemstillinger. På denne måde politiseredes salafismen, og dens ideologi begyndte for alvor at udgøre en alvorlig trussel mod det franske protektorat (ibid. 489 og 495). Neosalafiyya som ideologi gav nationalisterne mod på at kritisere og modarbejde protektoratets politiske og økonomiske lederskab. Bevægelsen kritiserede, at marokkanerne ikke var omfattet af diverse moderniseringsprojekter, som protektoratet havde implementeret. De følte sig marginaliseret, forbigået og uretfærdigt behandlet. Al-Fāsī og alWazzānī (samt unge nationalister) opponerede kraftigt mod protektoratets diskriminerende politik og formulerede deres eget moderniseringsprojekt, som tog udgangspunkt i den politiske og sociale virkelighed, landet befandt sig i. Her kan bl.a. nævnes retten til ytrings-, forenings- og forsamlingsfrihed samt 
$ø$ nsket om at reducere den økonomiske ulighed. Protektoratets politik var efter alt at dømme uforenelig med den magtfulde elites politiske og kulturelle visioner, som al-Fāsī og al-Wazzānī var en del af (Miller 2013, 497). Al-Fāsī var 'ālim-uddannet fra det prestigefyldte islamiske al-Qarawiyyin universitet i Fes og havde siden sine unge dage arbejdet ud fra den islamiske jurisprudens for at gøre islam kompatibel med modernitet. Han argumenterede for, at islam var den religion, der bedst bidrog til dannelsen af et retfærdigt og demokratisk samfund, og for at rationalitet var en central del af islam. I den henseende er det værd at understrege, at al-Fāsīs rationalistiske tankegang sigtede mod at forbinde sharī ' $a$ og den menneskelige fornuft. Denne tilgang forstærkedes af hans forkærlighed til de arabiske filosoffer, alFārābī, Ibn Sīnā og Ibn Rushd. Det var med udgangspunkt i deres filosofiske arbejde, at han gav sit bud på, hvordan landets sociale, økonomiske og politiske udfordringer bedst muligt kunne løses. Det betød, at han bekendte sig til den menneskelige fornuft og var positivt indstillet over for en moderne fortolkning af islam: "in the Islamic Sharia there is no imposing obligation, either in the terms of doctrine or of behaviour, that contradicts reasons" (Johnston 2007, 93).

Al-Wazzānī var derimod politolog-uddannet ved Institut d'Études Politiques i Paris og arbejdede primært ud fra Vestens liberale principper, der fungerede som omdrejningspunkt for hele hans politiske tænkning. Det betyder dog ikke, at han distancerede sig fra islams grundlæggende principper, men han var fortaler for et politisk system, hvor der var en klar adskillelse mellem religion og politik. Han anses for at være en af de få nationalister, der har beriget den marokkanske politiske sfære med en række toneangivende udgivelser, debatter og taler. I disse behandler han forskellige politiske aspekter, såsom borgerrettigheder, den nationale værdikamp og den politiske magt. Samtidig var han i sit politiske virke kendt for at være en indædt forkæmper for at få indført et demokratisk system, hvor ytringsfrihed spillede en central rolle.

Frontfigurerne al-Fāsī og al-Wazzānī formåede begge at teoretisere fremtidige politiske projekter baseret på liberale principper forbundet med en metafysisk forståelse. De udviste begejstring for individualisme, liberalisme, konstitutionalisme, retsstat og demokrati. I det følgende vil jeg belyse, hvordan deres politiske ideer og tanker forener liberalismen med islamiske principper.

Tidsskrift for Islamforskning 11 (1) · 2017 • 108-127 
Deres tanker og ideer kom allerede til udtryk i 1934, hvor protektoratets politik favoriserede franske bosætteres interesser i Marokko. Nationalisterne påbegyndte derfor et politisk oprør mod protektoratets reformer og begyndte så småt at udtrykke deres politiske ideer og meninger på en langt mere struktureret måde end tidligere. Tilsammen dannede de en fælles national front mod protektoratet ved at formulere Plan de Réformes, som indbefattede en række forskellige initiativer. Plan de Réformes blev af al-Fāsī opfattet som det første skridt mod selvstændighed, men også som et udtryk for, at det marokkanske folk skule inkluderes i reformprocessen. Overordnet set omfattede planen en række vigtige punkter. Af dem kan nævnes politiske, sociale og juridiske reformer, men også retten til at danne en nationalforsamling og indføre arabisk som Marokkos officielle sprog (al-Qiquri 2010, 68; al-Fāsī 1970, 137). Reformerne var præget af liberale ideer, fordi de nye frontfigurers politiske og religiøse holdninger var mere modernistiske end salafistiske. I den henseende udviste al-Fāsī og al-Wazzānī politisk ansvarlighed ved at fremhæve nødvendigheden af at indføre politiske reformer og skabe tidssvarende politiske institutioner. Al-Fāsī understregede, at moderne institutioner og moderne begreber var noget, der også tilfaldt det marokkanske samfund. Men moderniserings- og reformeringsprocessen måtte på ingen måde underminere landets islamiske integritet. Hele ideen med en sådan proces var at løfte det marokkanske samfund til samme niveau som de mest progressive samfund i verden. Hvis Vestens progressivitet skyldtes urbanisering, frihed og demokrati, så måtte begreberne også være forenelige med islam. Al-Fāsī anskuede salafismen som en ideologi, der tillod fornyelse, såfremt hensigten var at modernisere den islamiske civilisation (Bādū 2007, 341).

Al-Wazzānīs forståelse af Plan de Réformes tog udgangspunkt i det franske liberale tankesystem. Han retfærdiggjorde sine standpunkter ved at henvise til lignende islamiske institutioner og begrebsdefinitioner. På den måde undgik han, at konservative islamiske kredse stillede kritiske spørgsmål med hensyn til hans liberale holdninger. Det skal ikke forstås sådan, at han affærdigede islamiske principper. Tværtimod argumenterede han for, at der ingen forskel er mellem Vesten og islams grundlæggende principper og institutioner. Al-Wazzānī hævdede, at islam ligesom den franske revolution fremhæver broder- 
skab, lighed, retfærdighed og frihed. Det skal dog understreges, at al-Wazzānīs henvisninger til islamiske institutioner og begrebsdefinitioner blot retfærdiggjorde hans liberale holdninger. Uden sammenligningerne var det umuligt for ham at opnå den nødvendige støtte til sit moderniseringsprojekt (El-Mansour 1994, 66).

Både al-Fāsīs og al-Wazzānīs ideologiske overbevisning betragtes som epokegørende i Marokkos moderne politiske historie. Deres visioner afspejlede befolkningens behov og aspirationer i en tid, hvor moralen og selvtilliden var lav. Endvidere proklamerede de over for protektoratet retten til at etablere et konstitutionelt monarki, retten til at danne en national rådsforsamling, retten til at understøtte fundamentale borgerrettigheder og retten til at indføre obligatorisk skolegang for alle (Hoisington 1984, 40; Porter 2010, 564). Det er ingen hemmelighed, at Plan de Réformes var præget af et vestligt liberalt tankesæt, men planen blev alligevel afvist af det franske protektorat. Afvisningen bundede ifølge protektoratet $\mathrm{i}$, at Plan de Réformes var for teoretisk funderet og for besværlig at implementere i en traditionel stat som Marokko (Hoisington 1984, 40). Det fik reformisterne til at igangsætte en intellektuel frigørelsesbevægelse med det klare formål at udrydde det traditionelle tankesystem, der forhindrede landets frigørelse (Bādū 2007, 313). I den henseende skulle islam være det fundament, det marokkanske samfund skulle bygges på. Vigtigst af alt skulle irrationalisme, overtroiskhed og mysticisme erstattes af sande islamiske værdier.

\section{Det visionære politiske projekt}

En reform af Marokkos politiske system var et vigtigt aspekt af al-Fāsīs og al-Wazzānīs politiske tænkning og noget, de begge anså for at være en af de største udfordringer landet stod over for efter uafhængigheden. Begge ønskede, at landet implementerede et politisk system baseret på demokrati.

Indførelse af et parlamentarisk system ville, ifølge al-Fāsī, sikre individets ret til frihed. Til gengæld anså han det som en borgerpligt, at individet udviste social ansvarlighed ved at involvere sig i den politiske proces, og at hele den marokkanske befolkning støttede op om indførelse af et moderne politisk system. Men han erkendte, at det forudsatte et opgør med tradi- 
tionelle og reaktionære kræfter, der efter hans mening forhindrede landet $\mathrm{i}$ at udvikle sig i en positiv retning. Det fik al-Fāsī til at promovere et parlamentarisk system, der var foreneligt med islam (Dwyer 1991, 132-33). Ifølge al-Fāsī fordømmer islam korrupte og undertrykkende regimer. Han opfordrede derfor individet til at frigøre sig fra samfundsmæssig undertrykkelse. I islam er tankefrihed, ifølge al-Fāsī, en forudsætning for al menneskelig udvikling, så længe det ikke underminerer Allahs suverænitet. Det er derfor vigtigt, at marokkanerne lægger afstand til en blind og ureflekteret imitation af forfædrenes forældede fortolkninger af islam (al-Fasi 1953, 9). Frihed var for al-Fāsī ikke blot et vestligt begreb, men et begreb der allerede eksisterede i islam, og foruden retten til ytringsfrihed indbefattede det også respekt for individets værdighed (Al-Rīsūnī 2009, 297): "freedom of thought and freedom from corruption have always been regarded by Islam as the essential perquisites of the progress of mankind and as the focal point of all social reform" (al-Fasi 1953, 9). Frihed vil på den måde frigøre mennesket fra undertrykkelse og skabe grobund for fællesskabet. Men frihed vil også danne rammen for etableringen at et parlamentarisk system (al-Fāsī 2008, 59). Trods sit indgående kendskab til liberalisme, marxisme og socialisme kastede al-Fāsī sig ikke ud i blind imitation af disse ideologier. Tværtimod var hans strategi at udvælge bestemte vestlige begreber, som han mente var i harmoni med Marokkos politiske kultur og islamiske identitet. Landets islamiske kultur og historie var for ham grundstenen for en succesfuld indførelse af et konstitutionelt monarki, der er tilpasset den marokkanske virkelighed. Hans krav var blot, at det marokkanske monarki fulgte med samfundsudviklingen. Det skal understreges, at al-Fāsī var en indædt fortaler for bevaringen af monarkiet, og at han var opsat på at udtænke nye strategier for, hvordan man sikrede monarkiets fortsatte eksistens bedst muligt (Shaqīr 2009, 28).

Al-Wazzānī delte ikke samme begejstring for monarkiet som al-Fāsī, især ikke hvad angik dets indblanding i landets politiske sfære. Han så helst et politisk system, der afspejlede et vestligt konstitutionelt monarki (Vingradov \& Waterbury 1971, 52). AlFāsī og al-Wazzānī formåede inden etableringen af nationalstaten at udarbejde rammerne for indførelsen af demokrati. Under protektoratet var de enige om at nedsætte et konstitutionsråd, der var fri for kongelig indblanding. Men dette ændrede 
sig, da den politiske magtbalance i slutningen af 1950'erne tippede til kongens fordel. Al-Fāsī og al-Wazzānī ændrede derfor standpunkt og accepterede, at Mohammed V udnævnte medlemmerne i det nye grundlovgivende forsamlingsråd. Rådet skulle efter kongens hensigt repræsentere alle dominerende politiske meninger og diskurser i samfundet (al-Fāsī 2008, 129; Shaqìr 2009, 32: Alport 1961, 206-7).

Der hersker ingen tvivl om, at både al-Fāsī og al-Wazzānī var interesserede $i$ at få vedtaget en ny konstitution så hurtigt som muligt. Men deres argumenter for at tilslutte sig kongens særlige udvalg var forskellige. Al-Fāsī var på det tidspunkt opsat på, at landet hurtigt fik vedtaget en ny konstitution, idet han var bekymret for, at den politiske ustabilitet i landet ville forværres yderligere og dermed udskyde implementeringen af et konstitutionelt monarki. Det spillede derfor ikke længere nogen rolle for al-Fāsī, om den nye konstitution blev udformet af kongen selv eller af et demokratisk valgt konstitutionsråd. Det, der var vigtigt for ham, var, at monarkiet som institution havde højeste prioritet i en enhver given problemstilling, og at landets traditionelle politiske system overgik fra enevælde til et konstitutionelt monarki (Shaqīr 2009, 29).

I den postkoloniale periode var al-Wazzānī ligesom al-Fāsī optaget af, at Marokko hurtigt fik vedtaget en ny forfatning. Målet var at få Marokko ud af den onde spiral, selvom forfatningen ikke levede op til hans forventninger. Han så gerne, at Marokko fik udskiftet det traditionelle politiske system med et tidsvarende og moderne politisk system. Trods sit liberale standpunkt stillede al-Wazzānī efter selvstændigheden i 1956 ingen krav til, hvordan den grundlovgivende forsamling skulle udformes. Selvom han tidligere havde prioriteret det højt, var det nu vigtigere for ham, at hans parti fik mest muligt politisk indflydelse vis-à-vis al-Fāsīs parti (Shaqīr 2009, 114-15). At hans rival al-Fāsī blev valgt som formand for rådet, tvang derfor alWazzānī til at tage den drastiske beslutning at melde sig ud af konstitutionsrådet. Det betød naturligvis, at konstitutionen uden videre defineredes af kongen selv med støtte fra hans politiske allierede, herunder al-Fāsī (Shaqīr 2009, 119). Med hensyn til monarkens fremtidige indblanding i det politiske system betonede al-Wazzānī, at kongen på ingen måde skulle spille en rolle i det nye politiske system. Hele ideen med indførelsen af konstitutionen udgjorde, ifølge al-Wazzānī, en nøglefaktor i indskrænkningen af monarkens politiske magt. 


\section{Hvordan skal den nye konstitution udformes?}

Udformningen af landets første konstitution spillede en kæmpemæssig rolle for reformisterne efter selvstændigheden. Selvom al-Fāsī argumenterede for implementering af et konstitutionelt monarki, fastholdt han samtidig, at kongen skulle spille en rolle i det politiske system. Det betød, at han var positiv stemt over for kongehuset, og at forfatningen skulle tage hensyn til kongens tidligere politiske, sociale og religiøse rolle i det marokkanske samfund. Med det argument var han sikker på, at kongens indblanding i det politiske system ikke ville medføre en indskrænkelse af den folkelige suverænitet. Efter hans vurdering ville monarkiets fortsatte indblanding i den politiske sfære og dets rolle i samfundet blot betyde, at monarken stadig skulle besidde retten til at herske og reagere i landet. Ydermere var det vigtigt, at konstitutionen ikke begrænsede monarkens politiske magt, fordi Marokko befandt sig i en periode, der var præget af politisk ustabilitet. Det var altså, ifølge al-Fāsī, kun kongen, der kunne skabe sikkerhed, stabilitet og fremgang i landet (Shaqīr 2009, 31). Monarkiet skulle som institution bidrage til udviklingen af den politiske proces i en mere demokratisk og fredelig retning, især efter at Marokko i perioden fra 1956-1962 havde været præget af intense politiske og personlige stridigheder og voldelige optøjer, der underminerede den politiske stabilitet. I realiteten skulle konstitutionen både sikre og helliggøre monarkiets prærogativer og samtidig fungere som et politisk instrument, inden for hvilket monarken styrede og overvågede landets interne anliggender. Samtidig skulle monarkiet, som det altid har gjort, have en symbolsk værdi og repræsentere alle befolkningsgrupper i samfundet. Kongen skal med andre ord agere som national og symbolsk samlingsfigur i kraft af sin rolle som amìr al-mu'minin (de troendes leder) (Shaqīr 2009, 32). Endvidere mente al-Fāsī, at monarkiet skulle bevare dets oprindelige struktur, men med tiden udvikle sig til et konstitutionelt monarki på linje med det britiske monarki (al-Fāsī 1970, 170). Kongen skulle ikke agere som aristokrat, men pålægges en ny rolle som repræsentant for landet og udvise underdanighed over for folket som foreskrevet i sharī 'aen (Shawn 1984, 54). Under hele sit politiske virke var al-Fāsī en indædt fortaler for bevarelsen af monarkiet. Det skyldtes, at han som 'ālim (muslimsk lærd) følte sig forpligtet til at udvise social og religiøs ansvar- 
lighed over for befolkningen med henblik på at sikre sig mod et samfund præget af anarki. Ifølge hans overbevisning skete det bedst ved at inddrage monarken i det fremtidige politiske arbejde.

Med inspiration fra de vestlige landes politiske systemer ønskede al-Wazzānī derimod en forfatning, der byggede på et vestligt tankegods. Han forestillede sig et politisk system, som tog udgangspunkt i vestlige liberale principper, og som støttede op om demokrati, ligestilling og social retfærdighed. Hans politiske visioner om en demokratisk politisk styreform var mere liberalt funderet og systematiseret end al-Fāsīs. Al-Wazzānī ønskede, at magten skulle ligge hos folket, og at monarken alene spillede en ceremoniel rolle i den politiske sfære. For at realisere et sådant demokratisk projekt fandt al-Wazzānī det nødvendigt, at der blev taget et afgørende skridt væk fra enevælde og henimod et folkestyre ledet af folkevalgte repræsentanter, og hvor grundlæggende borgerrettigheder respekteredes. De folkevalgte skulle agere som folkets talerør i parlamentet, hvor de, og ikke kongen, havde det overordnede politiske ansvar. For alWazzānī var det repræsentative system en hjørnesten i en demokratisk styreform, men han erkendte, at Marokko led under et demokratisk underskud, og at der derfor var lang vej til målet. For at komme problemet til livs fandt han det nødvendigt, at den marokkanske borger deltog aktivt i opbyggelsen af et demokratisk samfund. Men det var ikke kun den marokkanske befolkning, der skulle gøre en indsats. Det var i den grad medlemmerne og repræsentanterne i parlamentet, der havde ansvaret for at hjælpe befolkningen med at opnå større politisk modenhed ved at give borgerne politiske rettigheder. Det betød eksempelvis, at hvis blot en vælgers fundamentale stemmeret blev tilsidesat under et valg, skulle det betragtes som et brud på en af demokratiets grundpiller, nemlig den folkelige suverænitet.

Selvom al-Wazzānī nærede store forhåbninger for det unge demokrati i landet, måtte han sande, at kommunalvalget i 1960 ikke levede op til hans forventninger. Her led hans demokratidrømme et alvorligt knæk, fordi valget bar præg af omfattende svindel og manipulation med valgresultaterne (Shaqï 2009, 93). Hvorvidt al-Wazzānī var overrasket over den massive valgsvindel ved vi ikke, men som Douglas Ashford understreger, så skal man udvise forbehold over for et land, hvis styreform er enevæl- 
de (Ashford 1961, 1). Al-Wazzānīs mistanke om valgsvindel fik ham til at formulere en række forslag, der skulle sikre et valgsystem fri for svindel og korruption. Han opstillede en række punkter herunder vigtigheden af at have et godt udvalg af kandidater, reformere partiloven og skabe en sund demokratisk kultur. Tiltagene havde til formål at etablere et parlamentarisk system, sikre frie og demokratiske valg. Endnu vigtigere fandt han det nødvendigt, at parlamentet også bestod af oppositionspartier, og at juridiske rettigheder såsom ytrings-, forenings- og forsamlingsfrihed blev indskrevet i konstitutionen (Shaqī 2009, 95-6). Al-Wazzānī var ikke kun optaget af demokratiske teorier, men også af måden, hvorpå teorierne skulle anvendes i det politiske system - f.eks. hvordan man bedst muligt sikrer sig en bæredygtig forvaltning af offentlige anliggender. Han så gerne en ny konstitution, der værnede om demokratiet og demokratiske institutioner samt indskrænkede monarkens politiske prærogativer, hvad angik landets inden- og udenrigspolitiske sfærer. På denne måde kunne Marokko have undgået den politiske krise, da Kong Hassan II (r. 1961-99) erklærede undtagelsestilstand i 1965 (Shaqīr 2009, 97). Al-Wazzānī ønskede en konstitution, der præcist definerede, hvad monarken kunne tillade sig i marokkansk politik. Kongens politiske manøvrer i 1965 signalerede, ifølge al-Wazzānī, mangel på efterlevelse af og respekt for landets første konstitution, som blev vedtaget i 1962. Ifølge ham, formåede Hassan II efter sin indsættelse på kort tid at undergrave princippet om magtens tredeling - den dømmende, den lovgivende og den udøvende magt. Magtens tredeling skulle skabe en politisk platform, der regulerede og definerede måden, hvorpå politiske repræsentanter og monarken skulle agere i enhver given politisk kontekst. På sigt skulle tredelingen sikre den folkelige suverænitet, der med tiden skulle betragtes som et vitalt og helligt aspekt i marokkansk politisk. Ifølge al-Wazzānī sikredes den folkelige suverænitet bedst ved en fornuftig balance mellem den lovgivende, den dømmende og den udøvende magt, og på den måde ville det føre til en progressiv stat, hvor det autoritære system blev erstattet af en demokratisk styreform, der fratog monarkiet retten til politisk indblanding (Shaqīr 2009, 100-1). 


\section{Konstitutionelt monarki - dets rolle i den post- koloniale periode}

Vedtagelsen af Marokkos første konstitution i 1962 banede vejen for indførelsen af et vestligt konstitutionelt monarki, hvor parlamentet skulle spille en ledende rolle. Det var et parlament, der ifølge al-Fāsī skulle kunne sammenlignes med den islamiske styreform kaldet al-shūrā. ${ }^{1}$ Al-Fāsī hævdede, at det parlamentariske demokrati og al-shūrā har samme funktion og betydning, som det altid har haft i islam. Han fortolkede al-shūrā som en konstruktion, hvor regenten i henhold til udlægningerne i islam er forpligtet til at konsultere med folket, uanset hvilken historisk eller politisk kontekst man befinder sig i. Al-Fāsī underbyggede sine udsagn ved at fremhæve konsultationsformaningerne foreskrevet i Koranen: "and consult with them upon the conduct of affairs" (2, al-'Imran, 159) og "and whose affairs are matter of counsel" (42, al-Shūrā, 38) (Shawn 1983, 48). Al-Fāsī mente, at al-shürā ikke skulle anskues som en fastlåst konstruktion, men som en konstruktion, der ændrer sig alt efter hvilken tid og hvilket sted muslimerne befinder sig i. Vigtigst af alt forstod han al-shūrā som et redskab, der kunne indskrænke regentens magt og samtidig fungere som omdrejningspunkt for hele hans forestilling om, hvordan et konstitutionelt monarki skulle udformes. Det lader til, at hans sammenligning af al-shūrā og konstitutionelt monarki sigtede mod at tilfredsstille det konservative religiøse etablissement, og at han forsøgte at undgå enhver mistanke om bid'a (fornyelse). ${ }^{2}$ I virkeligheden argumen-

1. Al-Jâbirī definerede al-shūrâ, "as consultation is an exchange of opinion, and seeking the opinion of whoever is capable of giving it. Again, 'taking the opinion' does not commit the 'taker', nor are the 'givers of opinion' specified. The latter are described as 'people capable of decision making', and those include anybody in the society with power, whether it is in the field of knowledge, economics or religious or social affairs, but without indication and quantity, quality, place or time." (al-Jâbirī 2009, 124).

2. Bid'a betyder en handling eller et påfund, der intet har med den sande islam at gøre. terede han snarere for, at Vestens demokrati i en islamisk kontekst svarede til det, som muslimer opfatter som al-shūrā (alJābirī 2009, 123-24). Al-Fāsīs ideelle parlamentariske system byggede på to vigtige punkter: 1) at ministerierne udviste politisk ansvarlighed, og 2) at befolkningen deltog aktivt i det politiske arbejde.

Det første punkt hvilede på dannelsen af et stabilt politisk system, der sikrede mod fremtidige politiske revolutioner, magtkampe og oprør. Ifølge ham, var det forhenværende ministres mangel på politisk ansvarlighed, der havde ført til politiske omvæltninger i den prækoloniale periode og medført, at folket rettede deres frustrationer mod den siddende sultan (al-Fāsī 2008, 127). Oprettelsen af nye ministerier med hver deres ansvarsområde skulle, ifølge al-Fāsī, have både en vestlig og islamisk side. 
Dvs. at ministerierne ud fra en vestlig perspektiv skulle stå til ansvar over for parlamentet, men ud fra et islamisk perspektiv skulle stå til ansvar over for monarken. Kombinationen af den islamiske og den vestlige politiske forvaltningsmodel (der kendetegner vestlige demokratier) ville, ifølge al-Fāsī, sikre et stabilt politisk system. Hermed understregede han, at monarken skulle fungere som parlamentets politiske overhoved. Principielt set forestillede han sig en politisk konstellation, hvor regeringen efterlevede og effektuerede monarkens love og dekreter (Shaqīr 2009, 34). I realiteten fratog en sådan konstruktion parlamentet dets demokratiske rettighed og brød med Vestens forståelse af demokrati. I en marokkansk parlamentarisk kontekst skulle ministerierne agere som monarkens stedfortrædere, men alene ministrene skulle holdes ansvarlige for deres handlinger. Dvs. at monarken ikke skulle holde ansvarlig for fremtidige konfrontationer og problemstillinger.

Det andet punkt sigtede mod inddragelsen af befolkningen i det politiske liv. Ifølge al-Fāsī er folkevalgte politikere i sig selv ikke et nyt fænomen i Marokko. Historisk set har pashaen og qāid'en haft indflydelse på lokale og centrale politiske områder, mens sultanen stod for den overordnede politik i landet (Akhavi 2003, 533). For al-Fāsī var demokrati ikke et ukendt fænomen, men derimod en styreform, der opstod på den Arabiske Halvø med islams fremkomst. Dvs. at islam for ham var en religion, der ophøjer humanisme, ligestilling og juridiske rettigheder. Med henvisning til landets tidligere politiske praksis argumenterede al-Fāsī for folkets ret til involvering i landets offentlige anliggender og til overvågning af de folkevalgte politikere (Shaqīr 2009, 35). Al-Fāsī fastholdt, at involveringen af folket i landets nationale anliggender ville styrke demokratiet, forstærke og sikre et dynamisk og stabilt samarbejde mellem monarkiet og folket samt genskabe Marokkos nationale stolthed (al-Fāsī 2008, 128). Den folkelige deltagelse var ikke kun forbeholdt et bestemt segment af befolkningen, men omfattede alle befolkningsgrupper uanset køn, race, religion og sociokulturelle baggrund (al-Fāsī 2008, 128).

I bund og grund ønskede al-Fāsī den samme politiske aktivisme som i Vesten, hvor befolkningen tilkendegiver deres politiske standpunkter til lokale, regionale og nationale valg. Derudover ønskede han, at nye politiske partier ville revolutionere den traditionelle politiske praksis og igangsætte en ny politisk 
kultur i Marokko. Al-Fāsī var i denne sammenhæng inspireret af Sovjetunionens politiske praksis, som han forener med islamisk jurisprudens for derigennem at retfærdiggøre folkets ret til at afskedige en politisk repræsentant (Shaqīr 2009, 39; Shawn 1983, 48). Alt i alt gjorde al-Fāsī sig nogle tanker om, hvordan man kunne skabe et godt samarbejde mellem de folkevalgte og kongen med det formål at skabe grobund for velstand og fremgang uden at underminere kongens rolle. Kongen skulle i sin rolle som amìr al-mu'minin styrke demokratiet, sikre social stabilitet og sammenhold. Al-Fāsī var i den forstand fortaler for et konstitutionelt monarki, hvor magten i første omgang tilfaldt den øverste politiske leder, dvs. den siddende konge. Men så snart befolkningen havde tilegnet sig de nødvendige demokratiske færdigheder skulle magten overdrages til dem (al-Fāsī 1970, 139). Ud fra et liberalt salafiyya-projekt forsøgte al-Fāsī at begrunde indførelsen af vestlige institutioner med argumenter funderet $\mathrm{i}$ islam.

Ligesom al-Fāsī fremhævede al-Wazzānī nødvendigheden af, at Marokko etablerede et konstitutionelt monarki, men i modsætning til al-Fāsī fastholdt han, at kongen kunne skulle spille en ceremoniel rolle. Modsat al-Fāsī var han imod, at kongen eller religiøse lærde i den politiske sfære tilegnede sig en guddommelig autoritet, som ville gøre dem urørlige og dermed obstruere hele den demokratiske proces (Maghraoui 2009, 123). Hans grundlæggende tankesæt var i den forstand langt mere sekulær end islamisk funderet, og han ønskede et politisk system i Marokko, der tog udgangspunkt i det franske politiske system. For ham var islam en religion, der tillader, at folket selv definerer den styreform, de ønsker at leve under. Med det argument forsøgte han at legitimere indførelsen af et konstitutionelt monarki understøttet af islams generelle principper om retfærdighed, frihed og respekt for individets meninger (el-Mansour 1994, 64-5). Al-Wazzānī vurderede, at en ændring fra enevældigt styre til konstitutionelt monarki ville sikre politiske rettigheder for den marokkanske befolkning. Overgangen til konstitutionelt monarki skulle på sigt sikre etableringen af politiske institutioner baseret på folkelig suverænitet. Han argumenterede for, at udformningen af et konstitutionelt monarki på ingen måde adskilte sig fra den politiske praksis under profeten Muhammed eller de retledede kaliffer (Shaqīr 2009, 107). Han så helst, at det traditionelle politiske system blev reformeret indefra. Dvs. ikke 
gennem folkelig opstand mod regimet, men ved at Makhzan (Marokkos ældste politiske institution) selv påtog sig reform-opgaven og sikrede at monarken i sidste ende fik en ceremoniel rolle på linje med Vestens konstitutionelle monarkier. Mest af alt var al-Wazzānī optaget af, at monarken blev frataget sine politiske prærogativer, så forvaltningen af landets politiske anliggender overgik til parlamentet. Monarken skulle dog fungere som landets statsoverhoved, men uden politisk indflydelse.

Det konstitutionelle monarki, som blev indført i 1962, levede dog ikke op til al-Wazzānīs forventninger, da kongen blev tildelt to afgørende roller i den nye forfatning. For det første fastslog artikel 19, at kongen var landets naturlige religiøse overhoved og derfor skulle agere som forsvarer for troen (islam): "The King, Amir al-Mumineen ... shall be the Supreme Representative of the Nation and the Symbol of the unity thereof. He shall be the Defender of the Faith and the Protector of the rights and liberties of the citizens, social groups and organization." Kongens rolle som de rettroendes leder blev yderligere styrket af artikel 23: "The King's person is inviolable and sacred." Den anden rolle, der blev tildelt kongen, havde ikke religiøs, men politisk karakter. Med artikel 24 fik han en afgørende politisk rolle med eneret til at udnævne og afskedige ministrene: "the King appoints and dismisses the ministers." Al-Wazzānī mente, at artiklerne i konstitutionen var et indgreb i den folkelige suverænitet, men også et angreb mod liberalismens grundlæggende principper (Shaqīr 2009, 108-9).

Al-Wazzānī gjorde sig, i den tidlige fase af den postkoloniale periode, store forhåbninger om, at landet ville få indført et politisk system med frie demokratiske valg. Han gjorde en dyd ud af at sammenligne islamiske begreber og institutioner med Vestens moderne institutioner og begreber. Et eksempel på dette er hans sammenligning af det islamiske begreb al-shūrā med et parlament. Med henvisning til al-shürā fastholdt han, at magten havde tilhørt den muslimske befolkning allerede under profetens tid, og at profeten bidrog til en styrkelse af den folkelige suverænitet ved selv at afstå fra at udpege en politisk efterfølger før sin død. Ifølge al-Wazzānī er den politiske praksis, som profeten og de retledte kaliffer førte, et bevis på, at den muslimske befolkning har ret til indflydelse (ibid. 125-26). Al-Wazzānī argumenterede yderligere for indførelsen af et konstitutionelt monarki ved at sammenligne det vestlige parlamentariske system 
med det muslimske bedested kaldet al-masjid (islamisk moske). For ham blev der i masjid’en ført politik, hvor folkevalgte repræsentanter diskuterede sociopolitiske emner, der førte til, at beslutningerne til sidst blev taget i fælleskab (ibid 2009.128-9). AlWazzānī formåede i den henseende at argumentere for, at islam ophøjer demokrati og respekterer folkesuverænitet, og at Vestens politiske institutioner ikke er uforenelige med tidligere islamiske institutioner. Til hans store skuffelse blev der i Marokko ikke indført parlamentarisk demokrati efter selvstændigheden, og situationen blev blot forværret af, at konstitutionerne i 1962 og 1970 stadfæstede kongens magtposition, så parlamentet og regeringen stod til ansvar for deres handlinger over for kongen. Hassan II's forfatningsmæssige ret til at udnævne og afskedige fungerende ministre underminerede princippet om et konstitutionelt monarki. Kongens dobbelte rolle som amìr almu'minin og landets politiske overhoved levede, ifølge alWazzānī, ikke op til Montesquieus teori om magtens tredeling.

\section{Konklusion}

I Marokko markerede liberal salafiyya, også kaldet neosalafiyyabevægelsen, sig både før og efter den koloniale periode i kraft af en ung og håbefuld generation af reformister, der stræbte efter politisk, økonomisk og social forandring. Reformisterne transformerede den religiøse salafiyya-bevægelse til en politisk bevægelse, der løftede Marokko ud af mere end 20 års politisk dødvande. De krævede en reform af landets institutioner, der afspejlede marokkanernes politiske aspirationer og beskyttede borgernes grundlæggende rettigheder. I den postkoloniale periode fortsatte den liberale salafiyya-ånd på trods af splittelsen i nationalbevægelsen, hvor al-Fāsī og al-Wazzānī for alvor brugte deres kræfter på at skabe et nødvendigt paradigmeskift i marokkansk politik.

Al-Fāsī forstillede sig et konstitutionelt monarki baseret på islamiske principper, hvor Mohammed V med den nyerhvervede titel som konge af Marokko skulle have det overordnede politiske ansvar. Førstnævnte udtænkte et nyt politisk system, der i høj grad var influeret af Vestens liberale værdier, dog kombineret med salafistisk tankegods. Mest af alt definerede han begreberne ytringsfrihed, partidannelse, stemmeret, demokrati og 
indførelse af et konstitutionelt monarki med udgangspunkt i Koranen og profeten Muhammeds sædvane.

Al-Wazzānī var derimod mere præget af Vestens liberale værdier end salafistiske principper. Han stræbte efter at indføre konstitutionelt monarki med det klare formål at indskrænke kongens politiske magt, således at parlamentet blev styrket. Overordnet set fremsatte både al-Fāsī og al-Wazzānī deres syn på, hvordan en reform af det traditionelle politiske system skulle udformes, og hvilke værdisæt der skulle prioriteres. Deres tanker var et resultat af den liberale salafiyya-ånd, der til en vis grad manifesterede sig i det marokkanske politiske miljø. Dette understreger, at liberalismen, som Vesten i dag har taget patent på, også vandt indpas i Marokko, selvom den metafysiske dimension spillede en dominerende rolle i al-Fāsīs og al-Wazzānīs politiske tænkning.

\section{Abstract in English}

This article explores the Moroccan concept of liberal salafiyya between the 1930s and 1960s. The concept was defined by the Moroccan thinker Muhammad 'Ābed al-Jābirī, who expounded the concept of an ideological school that originated in the 1930 and continued after Morocco regained its independence from France in 1956. Al-Jābirī argued that liberal salafiyya in Morocco arose from the merging of Western liberalism and Islamic traditional Salafism during the French colonial period (1912-1956). However, the ideologies of liberalism and Salafism had a different approach and adaptation in Morocco than the rest of the Arabic-Islamic world. This distinguishes Moroccan liberal Salafiyya from other expressions of Salafism in the Arabic world because it accepted liberalism as compatible with the fundamental principles of Salafiyya. Liberal Salafiyya was not only embraced by the Moroccan reformists Allāl al-Fāsī and Muhammad al-Wazzānī, but also by the Moroccan Sultan Muhammad $\mathrm{V}$ and the religious conservative establishment. The young reformists presented a "Plan de Réformes", where they demanded that the Moroccans should be part of the modernization process. The colonial power rejected their demands. This decision encouraged al-Fāsī and al-Wazzānī to define their own political projects in order to substitute the traditional political 
system with constitutional monarchy. After more than four decades of activism and struggle for incorporating a parliamentary system and modern political institutions, al-Fāsī and alWazzānī realised, that postcolonial Morocco was not ready to incorporate their political views.

\section{Litteratur}

Abun-Nasr, J. 1966. “The Salafiyya Movement in Morocco: The

Religious Bases of the Moroccan

Nationalist Movement." In

Wallerstein, Immanuel: Social

Change - The Colonial Situation.

John Wiley \& Sons, INC.

Akhavi, Shahrough. 2003. "Islam

and the West in World History"

In Third World Quartely 24 (3):

545-561.

Alport, E. A. 1961. "Morocco under the New King" In The World

Today 17 (5): 205-210.

Ashford, Douglas E. 1961. Political

Change in Morocco. Princeton

University Press.

Bādū, 'Abd al-Jalīl. 2007. Al-

Salafiyya wa al-Iṣlāh. Salīkhī

'Ikhwān - Ṭanjā.

Al-Fasi, Allal. 1953. "Muslims and the Present-day World" In The Islamic Review. July 1953.

Al-Fāsi, 'Alāl. 1970. The Independence Movements in Arab North Africa. Translated from Arabic by Hazem Zaki Nuseibeh. Octagon Books.

Al-Fāsī, 'Allāl. 2008. al-Nāqd alDhātī. Manshūrātu Mu’asasatu. 'Allāl Al-Fāsī, 8th edition.

Hoisington Jr, William A. 1984. The Casablanca Connection - French Colonial policy 1936-1943. The University of North Carolina Press. Chapel Hill and London. Hoisington, William A. 1995. Lyautey and the French Conquest of Morocco. Macmillan Press LTD.
Al-Jabri, Mohamed Abed. 2009. Democracy, Human Rights and Law in Islamic Thought. I.B. Tauris \& Co Ltd.

Al-Jābirī, 'Ābed Muhammad. 2006. Mawāqif. Dār al-Nashr alMaghribiyya.

Johnston, David L. 2007. "Allāl al-Fāsī: Shari'a as Bluprint for Righteous Global Citizenship.” in Amanat, Abbas \& Griffel, Frank: Sharia - Islamic Law in the Contemporary Context. Stanford University Press, California.

Maghraoui, Driss. 2009. "Ilmaniyya, Laïcité, Sécularisme/ Secularism in Morocco." In Gluck, Carol \& Tsing, Anna Lowenhaupt: Words in Motion. Duke University Press.

El Mansour, Mohamed. 1994. "Salafis and Modernists in the Moroccan Nationalist Movement." In Ruedy, John: Islamism and Secularism in North Africa. St. Martin's Press. New York.

Meijer, Roel. 2009. Global Salafism - Islam's New Religious Movement. Columbia University Press.

Miller, Susan Gilson. 2013. A history of modern Morocco. Cambridge University Press. Porter, Geoff. 2010. “The Qarawiyin Mosque Student Strike of 1937" In The Journal of North African Studie. 15 (4): 577-572.

Al-Qurqurī, Asīm. 2010. 'Allāl alFāsī -'Istirāthījītu Muqāwamatu al-'Isti'mār. Afrīqiyā al-Sharq. 
Al-Rīsūnī, Ahmad. 2009. Al-fikr al-Maqāṣidì bayna Muhammad al-T̄āhir bin 'Āshūr wa 'Allāl alFāsī. al-Harakhatu al-Salafìyatu fi al-Maghrib al-'Arabì. Mațba’tu al-'Mniyatu. Al-Ribāt.

Shaqīr, Būbakr. 2009. Al-fikr alSiyāsī al-Maghribī-Bayna al'Ithijāhāti al-Salafīyatu wa allibrāliyatu. Afrīqiyā al-Sharq.
Shaw, Ian. 1984. The Influence of Islam on the Political, Economic and Social Thought of Alläl al-

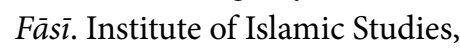
McGill University, Montreal (Unpublished).

Vinogradov, Amal \& Waterbury, John. 1971. "Situations of Contested Legitimacy in Morocco: An Alternative Framework" In Comparative Studies in Society and History. 13 (1): 32-59.
Wiktorowicz, Quintan. 2006. "Anatomy of the Salafi Movement" In Studies in Conflict \& Terrorism 29: 207-239. 